\title{
Article
}

\section{Restraint of Human Skin Fibroblast Motility, Migration, and Cell Surface Actin Dynamics, by Pannexin 1 and P2X7 Receptor Signaling}

\author{
Carolina Flores-Muñoz ${ }^{1,2}{ }^{\mathbb{D}}$, Jaime Maripillán ${ }^{1}$, Jacqueline Vásquez-Navarrete ${ }^{1}$, Joel Novoa-Molina ${ }^{1}$,
} Ricardo Ceriani ${ }^{1}$, Helmuth A. Sánchez ${ }^{1}$, Ana C. Abbott ${ }^{1}$, Caroline Weinstein-Oppenheimer ${ }^{3,4}$, Donald I. Brown ${ }^{5}$, Ana María Cárdenas ${ }^{1}$, Isaac E. García ${ }^{1,6}$ and Agustín D. Martínez ${ }^{1, *}$

check for

updates

Citation: Flores-Muñoz, C.;

Maripillán, J.; Vásquez-Navarrete, J.;

Novoa-Molina, J.; Ceriani, R.;

Sánchez, H.A.; Abbott, A.C.;

Weinstein-Oppenheimer, C.; Brown,

D.I.; Cárdenas, A.M.; et al. Restraint of Human Skin Fibroblast Motility, Migration, and Cell Surface Actin Dynamics, by Pannexin 1 and P2X7 Receptor Signaling. Int. J. Mol. Sci. 2021, 22, 1069. https://doi.org/ $10.3390 /$ ijms 22031069

Received: 30 November 2020

Accepted: 14 January 2021

Published: 22 January 2021

Publisher's Note: MDPI stays neutral with regard to jurisdictional claims in published maps and institutional affiliations.

Copyright: (c) 2021 by the authors. Licensee MDPI, Basel, Switzerland. This article is an open access article distributed under the terms and conditions of the Creative Commons Attribution (CC BY) license (https:/ / creativecommons.org/licenses/by/ $4.0 /)$.
1 Centro Interdisciplinario de Neurociencia de Valparaíso, Instituto de Neurociencia, Facultad de Ciencias, Universidad de Valparaíso, Valparaíso 2360102, Chile; carolina.flores@cinv.cl (C.F.-M.); jaime.maripillan@cinv.cl (J.M.); jacqueline.vasquez@cinv.cl (J.V.-N.); joel.novoa@cinv.cl (J.N.-M.); ricardo.ceriani@cinv.cl (R.C.); helmuth.sanchez@cinv.cl (H.A.S.); ana.abbott@cinv.cl (A.C.A.); ana.cardenas@uv.cl (A.M.C.); isaac.garcia@uv.cl (I.E.G.)

2 Programa de Doctorado en Ciencias, Mención Neurociencia, Universidad de Valparaíso, Valparaíso 2340000, Chile

3 Escuela de Química y Farmacia, Facultad de Farmacia, Universidad de Valparaíso, Valparaíso 2360102, Chile; caroline.weinstein@uv.cl

4 Centro de Investigación Farmacopea Chilena, Valparaíso 2360102, Chile

5 Laboratorio de Biología de la Reproducción y del Desarrollo, Instituto de Biología, Facultad de Ciencias, Universidad de Valparaíso, Valparaíso 2340000, Chile; donald.brown@uv.cl

6 Laboratorio de Fisiología Molecular y Biofísica, Facultad de Odontología, Universidad de Valparaíso, Valparaíso 2360004, Chile

* Correspondence: agustin.martinez@uv.cl; Tel.: +56-32-250-8415

\begin{abstract}
Wound healing is a dynamic process required to maintain skin integrity and which relies on the precise migration of different cell types. A key molecule that regulates this process is ATP. However, the mechanisms involved in extracellular ATP management are poorly understood, particularly in the human dermis. Here, we explore the role, in human fibroblast migration during wound healing, of Pannexin 1 channels and their relationship with purinergic signals and in vivo cell surface filamentous actin dynamics. Using siRNA against Panx isoforms and different Panx1 channel inhibitors, we demonstrate in cultured human dermal fibroblasts that the absence or inhibition of Panx1 channels accelerates cell migration, increases single-cell motility, and promotes actin redistribution. These changes occur through a mechanism that involves the release of ATP to the extracellular space through a Panx1-dependent mechanism and the activation of the purinergic receptor P2X7. Together, these findings point to a pivotal role of Panx1 channels in skin fibroblast migration and suggest that these channels could be a useful pharmacological target to promote damaged skin healing.
\end{abstract}

Keywords: pannexin 1; actin cytoskeleton; cell migration; wound healing; human dermal fibroblasts; purinergic receptor

\section{Introduction}

Pannexin (Panx) channels are transmembrane proteins involved in cell communication. There are three Panx isoforms: Panx1, Panx2, and Panx3, which form channels with a large vestibule and increase their activity under several physiological stimuli [1-4]. It is well documented that the activity of Panx1 channels allows adenosine triphosphate (ATP) release to the extracellular space [1], which activates purinergic receptors and causes the activation of intracellular signaling cascades [5]. In addition, it has been suggested that Panx1 channels interact with the ionotropic purinergic receptor, P2X7 (P2X7R) [1,6,7], such that stimulation of P2X7R with ATP increases the open probability of Panx1 channels [8], suggesting 
the existence of a positive feedback mechanism that results in the release of additional ATP. It has been proposed that ATP-mediated purinergic signaling plays important and diverse roles in skin physiology and wound healing [9]. For example, the activation of the inflammatory response orchestrates a fine-tuning mechanism required to achieve effective cellular migration, which involves rearrangements of the cytoskeletal dynamics $[10,11]$ mediated by actin and the small Rho GTPases family [12].

Despite the proposed role of connexins during normal skin repair and wound healing [13-18], little is known about the contribution of Panxs to these processes. It is well known that Panx1 and Panx3 are expressed in human and rodent keratinocytes [19-24], whereas Panx2 is expressed in the central nervous system $[25,26]$. Interestingly, the overexpression of Panx1 in rat epidermal keratinocytes reduces their proliferation rate and disrupts normal differentiation [20]. In contrast, the absence of Panx1 promotes fibroblast proliferation and reduces their differentiation in response to TGF- $\beta$ [21]. Moreover, skin Panx1 expression, which diminishes with age, is up-regulated after skin injury [20], suggesting a role in the wound healing process. Penuela and colleagues [21] found that keratinocytes from Panx1 knock-out animals (Panx1 KO) migrate more efficiently than do wild-type (WT) keratinocytes, suggesting that Panx1 is involved in regulating the migration rate in this cell type in response to tissue damage. In addition, in dendritic cells, Panx1 participates in a positive feedback loop that potentiates dendritic cell motility induced by ATP that permeates through these channels [27]. By contrast, Wicki-Stordeur and Swayne [28], using small interfering RNA (siRNA) against Panx1, found that reduction in Panx1 expression slows down cell migration in neuroblasts. Overall, these results suggest that Panx1 is involved in cell motility and migration and, depending on cell type, the activity of Panx1 channels can accelerate or reduce cell migration. However, whether these processes are under Panx regulation in human skin cells has yet to be determined. Here, we investigated the possible role of Panx1 channels and purinergic signaling in human dermal fibroblast (HDFs) migration and proposed a possible mechanism for wound repair that involves modulation of cell surface F-actin dynamics.

\section{Results}

\subsection{Inhibition or Blockage of Panx1 Channels Accelerates the In Vitro Wound Healing of HDFs}

As previously described and characterized by [21,23], we found that using RT-PCR and Western blot analyses of HDF cultures, Panx1 and Panx3 are expressed in primary HDFs (Figure 1A,B). We then determined the role of Panx1 channels during the migration process using an in vitro wound-healing assay on cultured HDFs (see Section 4). Under control conditions, HDFs repopulated about $50 \%$ of the wounded area $12 \mathrm{~h}$ post-injury, reaching almost complete closure of the wound area after $24 \mathrm{~h}$ post-injury (Figure 1C,D; Supplementary Figure S1A). To test if Panxs participate in this process, HDFs were bathed in a solution containing either $200 \mu \mathrm{M}$ probenecid (PBN), a non-selective Panx1 channel inhibitor, or $100 \mu \mathrm{M}^{10}$ Panx, a selective Panx1 blocker [29,30]. Both treatments accelerated the healing process, leading to nearly complete wound closure within $12 \mathrm{~h}$ post-injury. Importantly, this effect was not observed when cells were treated with a scrambled mimetic peptide (Sc ${ }^{10}$ Panx, $\left.100 \mu \mathrm{M}\right)$ (Figure 1C,D).

To more specifically address the potential role of Panx1 or Panx3 in wound closure, we used siRNA-GFP for selective reduction in Panx expression in HDFs. The expression levels of Panx1 and Panx3 were significantly reduced by around $70 \%$ and $60 \%$, respectively, after $24 \mathrm{~h}$ of transfection with the specific plasmid siRNA compared with the control plasmid (Figure 2C). We then evaluated the migration index, defined as the number of cells expressing siRNA-GFP in the migration front of the wound area (10-15 cell rows from the migration front; see Section 4), compared to non-transfected cells. As expected, the proportion of HDF cells expressing the control plasmid did not change (Figure 2A,B; Supplementary Figure S1B) between 0 and $9 \mathrm{~h}$ after the wound. By contrast, the proportion of cells expressing the siRNA against Panx1 increased in a time-dependent manner with respect to non-transfected cells in the migration front (Figure 2A,B; Supplementary Figure S1B). 
A similar experimental strategy was applied to investigate the role of Panx3 in the healing process. Using a siRNA against Panx3, we observed that the migration index for cells expressing siRNA-Panx3 reached a maximum level at $3 \mathrm{~h}$ post-injury, with no further increases during the remaining recording time (Figure 2A,B; Supplementary Figure S1B).
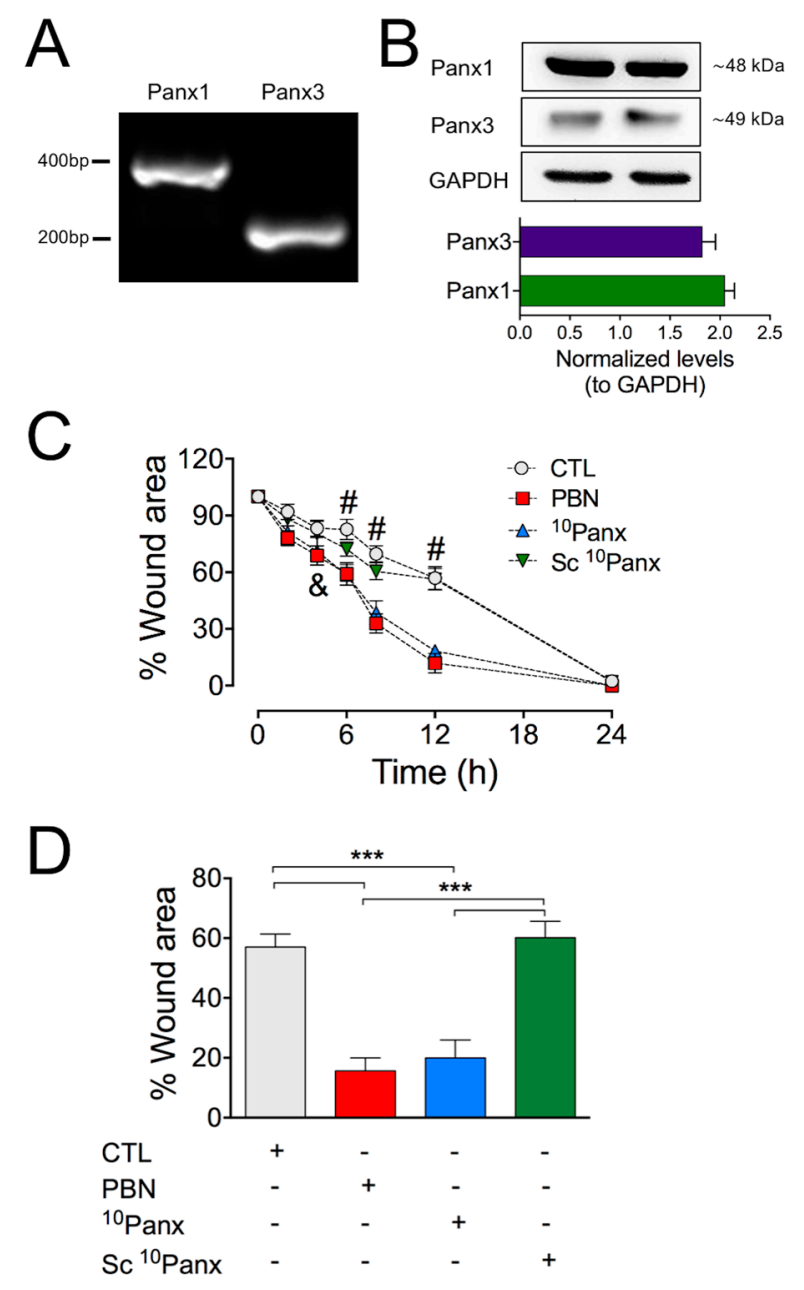

Figure 1. Inhibition of Panx1 channels accelerates wound closure in HDF cultures. (A) RT-PCR analysis of Panx1 and Panx3 mRNA in HDFs. (B) Representative Western blot showing protein levels of Panx1 and Panx3 in homogenates of HDFs. GAPDH immunodetection was used as a loading control. The graph shows the normalized levels of Panx1 and Panx3 in respect to GAPDH expression from $6 \mathrm{HDF}$ cultures. (C) Time course of the wound healing process in HDF cultures. The scratch area was expressed as the percentage of wound area at each time relative to $0 \mathrm{~h}$. CTL: control (untreated cultures). Panx1 channels were blocked using probenecid (PBN, $200 \mu \mathrm{M}$ ) and the mimetic peptide ${ }^{10} \mathrm{Pan} x 1\left({ }^{10} \mathrm{Panx}, 100 \mu \mathrm{M}\right)$. The scrambled peptide was used as control (Sc $\left.{ }^{10} \mathrm{Panx}, 100 \mu \mathrm{M}\right)$. Statistical significance was found between controls and PBN or ${ }^{10}$ Panx1. \& $={ }^{*} p<0.05$ for $4 \mathrm{~h}$; $\#={ }^{* * *} p<0.001$ for 6, 8, and $12 \mathrm{~h} ; n=10$ (two-way ANOVA followed by Bonferroni's post hoc test). (D) Comparison between wound healing rates $12 \mathrm{~h}$ after scratching for each treatment. ${ }^{* * *} p<0.001 ; n=10$ (two-way ANOVA followed by Tukey's post hoc test). All data are shown as mean \pm SEM, $n=10$ experimental replicas from at least four different cultures. Supplementary Figure S1A shows representative images of these experiments.

To further address the role of Panx1 in wound healing, we used primary fibroblast cultures from the skin of Panx1 knock-out mouse (MDF Panx1-/- $)$, which express Panx3 normally (Supplementary Figure S2A,B). The wound-healing assay in $\mathrm{MDF}^{\mathrm{Panx} 1-/-}$ revealed a tendency to accelerate wound closure within the first $12 \mathrm{~h}$ when compared with HDF and WT mouse dermal fibroblast (MDF) cultures (Supplementary Figure S2C,D). 


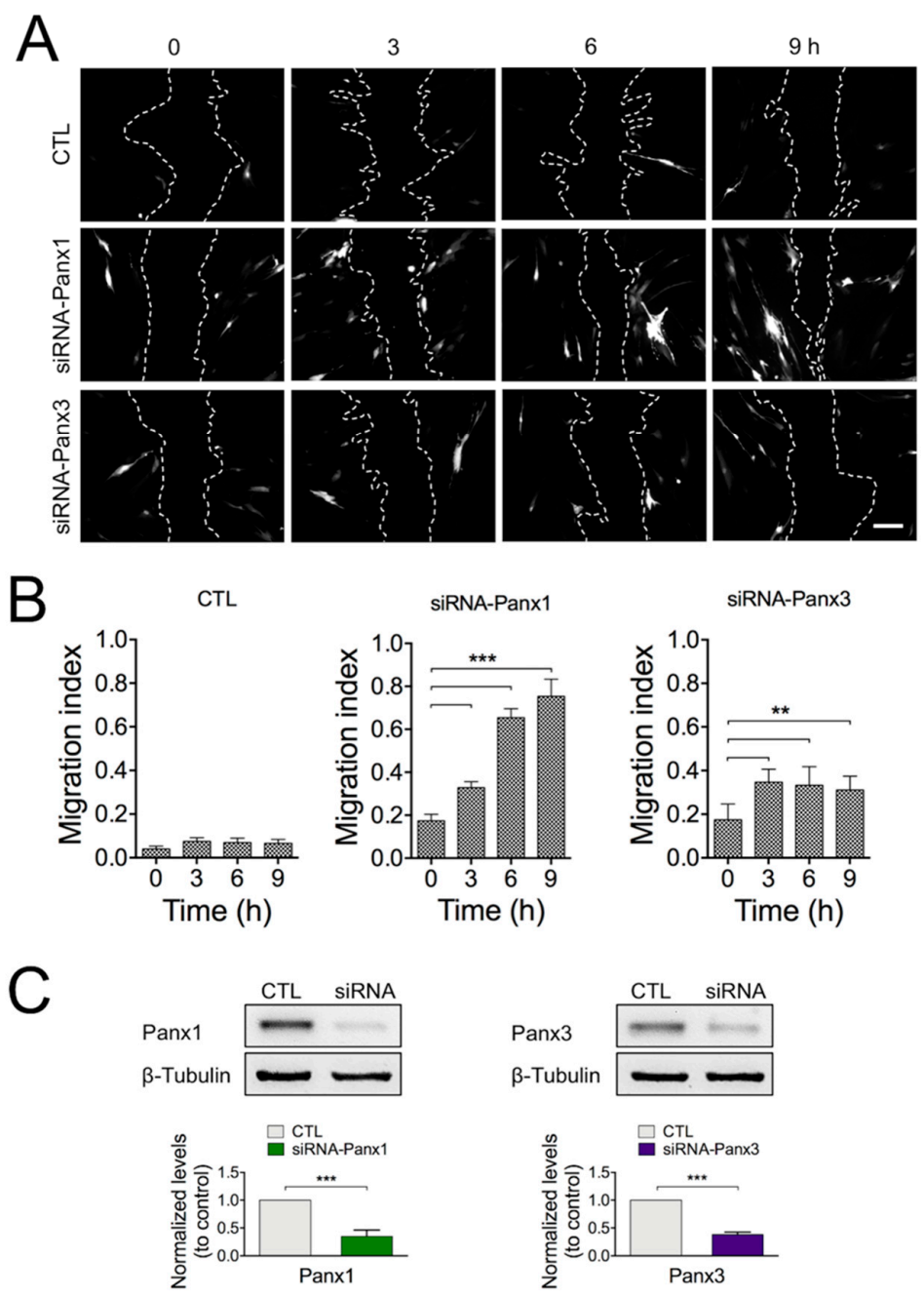

Figure 2. siRNA against Panx1 increases the migration index in HDF cultures. (A) Representative images of the wound healing process in cultures using Panx1 or Panx3 knockdown cells. HDFs transfected with siRNAs against Panx1, Panx3, or the control plasmid (CTL; siRNA-Empty-GFP) were identified by GFP expression. Dashed lines indicate the wound area (or the migration front line). Bar: $200 \mu \mathrm{M}$. Supplementary Figure S1B shows these same fluorescent images superimposed with their respective bright-field images. (B) Quantitative analysis of the average migration index $24 \mathrm{~h}$ after transfection of HDFs with respective siRNAs and CTL plasmid. Statistical significance ${ }^{* *} p=0.011$; *** $p<0.001 ; n=10$ experimental replicas from 4 different cultures (one-way ANOVA followed by Tukey's post hoc test). (C) Representative Western blots of Panx1 and Panx3 expression levels in total lysates from HDFs $12 \mathrm{~h}$ post-transfection. Graphs depicting the relative amount of Panx1 and Panx3 normalized to $\beta$-Tubulin from 4 different cultures. ${ }^{* *} p<0.001$ for siRNA fibroblasts compared to control (unpaired two-tailed $t$-test). All data are shown as mean $\pm \mathrm{SEM}$.

\subsection{Activity of Panx1 Channels during Wound Healing in HDF Cultures}

We have determined that Panx1 channels are involved in the regulation of the migration rate of HDFs. To explore to what extent the functional activity of Panx1 channels is affected during wound healing, we determined the temporal course of ethidium uptake (Etd) [31] in control cells and in cells treated with PBN, ${ }^{10} \mathrm{Panx}$, or Sc ${ }^{10} \mathrm{Panx}$ (Figure 3A; Supplementary Figure S3A). An increased number of Etd-stained nuclei was found $3 \mathrm{~h}$ after scratching in CTL and Sc ${ }^{10}$ Panx-treated HDFs, which was greatly reduced in cells treated with the Panx1 channel blockers PBN and ${ }^{10}$ Panx (Figure 3A).

In order to better quantify the Panx1 channel's activity, we determined the Etd uptake rate at different times during wound healing. The relative fluorescent intensities measured at the edge of the wound area immediately after inducing the wound $(0 \mathrm{~h})$ showed a 
low basal Etd uptake rate $\left(0.83 \pm 0.03 \mathrm{~F} / \mathrm{F}_{0} \mathrm{~min}^{-1}\right)$, which was not affected by Panx1 blockers ( $0.53 \pm 0.01 \mathrm{~F} / \mathrm{F}_{0} \mathrm{~min}^{-1}$ for PBN; $0.65 \pm 0.01 \mathrm{~F} / \mathrm{F}_{0} \mathrm{~min}^{-1}$ for ${ }^{10} \mathrm{Panx}$ ) (Figure 3B). However, an increased Etd uptake was observed at 3, 6, and $9 \mathrm{~h}$, after inducing the wound $\left(3.03 \pm 0.05 \mathrm{~F} / \mathrm{F}_{0} \mathrm{~min}^{-1}\right.$ at $3 \mathrm{~h} ; 4.52 \pm 0.05 \mathrm{~F} / \mathrm{F}_{0} \mathrm{~min}^{-1}$ at $6 \mathrm{~h} ; 5.36 \pm 0.03 \mathrm{~F} / \mathrm{F}_{0} \mathrm{~min}^{-1}$ at $9 \mathrm{~h})$, which was sensitive to Panx1 blockers [(at $3 \mathrm{~h}\left(0.86 \pm 0.02 \mathrm{~F} / \mathrm{F}_{0} \mathrm{~min}^{-1}\right.$ for PBN; $0.71 \pm 0.04 \mathrm{~F} / \mathrm{F}_{0} \min ^{-1}$ for $\left.{ }^{10} \mathrm{Panx}\right)$; at $6 \mathrm{~h}\left(0.72 \pm 0.05 \mathrm{~F} / \mathrm{F}_{0} \mathrm{~min}^{-1}\right.$ for PBN; $0.62 \pm 0.05 \mathrm{~F} / \mathrm{F}_{0} \mathrm{~min}^{-1}$ for $\left.{ }^{10} \mathrm{Panx}\right)$; at $9 \mathrm{~h}\left(0.38 \pm 0.04 \mathrm{~F} / \mathrm{F}_{0} \mathrm{~min}^{-1}\right.$ for PBN; $0.49 \pm 0.05 \mathrm{~F} / \mathrm{F}_{0} \mathrm{~min}^{-1}$ for $\left.{ }^{10} \mathrm{Panx}\right)$ ] (Figure 3B). Treatment with $\mathrm{Sc}^{10} \mathrm{Panx}$ did not significantly affect dye uptake [at $0 \mathrm{~h}\left(0.58 \pm 0.04 \mathrm{~F} / \mathrm{F}_{0} \mathrm{~min}^{-1}\right)$; at $3 \mathrm{~h}\left(3.02 \pm 0.03 \mathrm{~F} / \mathrm{F}_{0} \mathrm{~min}^{-1}\right)$, at $6 \mathrm{~h}\left(4.34 \pm 0.01 \mathrm{~F} / \mathrm{F}_{0} \mathrm{~min}^{-1}\right)$; at $\left.9 \mathrm{~h}\left(5.24 \pm 0.05 \mathrm{~F} / \mathrm{F}_{0} \mathrm{~min}^{-1}\right)\right]$ (Figure 3B). These results reveal that Panx1 channels are active during wound healing assays of HDF cultures and that this channel's activity increases as wound closure progresses.

A
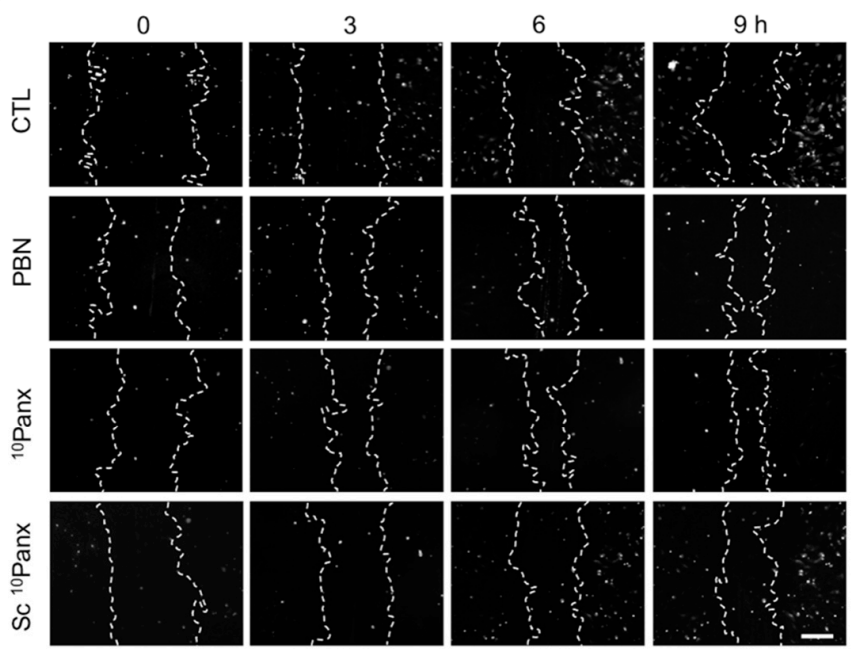

$\mathrm{B}$
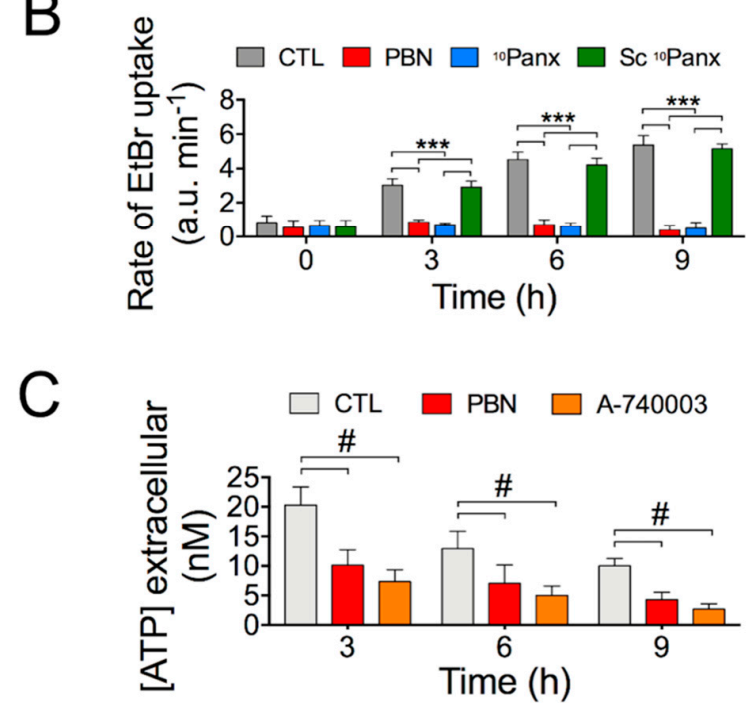

Figure 3. Activity of Panx1 channels during wound closure in HDFs. (A) Representative fluorescent images of Ethidium (Etd) uptake by HDF cells treated with $200 \mu \mathrm{M}$ PBN, $100 \mu \mathrm{M}^{10} \mathrm{Panx}, 100 \mu \mathrm{M}$ Sc ${ }^{10}$ Panx, or vehicle (Control, CTL). Bar: $200 \mu \mathrm{m}$. Supplementary Figure S3A shows these same fluorescent images superimposed with their respective bright-field image. (B) Etd uptake rate measure as described in Section $4 ;{ }^{* * *} p<0.001 ; n=10$ (two-way ANOVA followed by Bonferroni's post hoc test). (C) Measurements of extracellular ATP released from HDFs as a function of time in the presence or absence of $200 \mu \mathrm{M}$ PBN or $10 \mu \mathrm{M}$ A-740003. \#: *** $p<0.001 ; n=10$ (two-way ANOVA followed by Tukey's post hoc test). All data are shown as mean \pm SEM. 
It has been widely reported that ATP can be released through Panxs channels $[1,30]$. Thus, we determined the amount of ATP released by HDFs during wound closure using a luminescence-based assay. The increase in extracellular ATP concentration induced by the wound was significantly reduced by $200 \mu \mathrm{M}$ PBN (Figure 3C). In addition, we measured extracellular ATP concentration after $12 \mathrm{~h}$ of wound healing in MDF and MDFPanx1-/- cultures and found a significant increase in ATP in MDFs compared with $\mathrm{MDF}^{\mathrm{Panx} 1-/-}$; this increase was prevented by the Panx1 blocker PBN (200 $\mu$ M PBN) (Supplementary Figure S2G). These results suggest that Panx1 channels contribute to the wound healing-induced ATP release from these cells.

As mentioned above, cell proliferation is also part of the mechanism triggered by wound healing. To rule out the possibility that wound closure following Panx1 channels inhibition was due to cell proliferation stimulation, we used a proliferating cell nuclear antigen (PCNA) antibody, a well-known cell proliferation marker [28]. We did not observe significant differences in the expression of PCNA during wound closure at any time and under any treatment tested (Supplementary Figure S3B), which strongly suggests that the blockade of Panx1 channels modulates wound closure of HDF cultures by a mechanism that involves cell migration rather than cell proliferation.

\subsection{Blocking the Purinergic P2X7 Receptor Significantly Accelerates Wound Healing in HDF Cultures}

Since we showed that ATP release by HDFs is strongly reduced by blockade of Panx1 channels, we decided to evaluate if extracellular ATP modulates in vitro healing in HDFs. For this, we used apyrase, which catalyzes the degradation of extracellular ATP. Cells that were subjected to the wound assay were treated with $10 \mathrm{U} / \mathrm{mL}$ of apyrase for $24 \mathrm{~h}$. We found that apyrase treatment accelerated the wound area's reduction (Figure 4A,B), suggesting that endogenous ATP slows down migration.

It is known that HDF cells express purinergic receptors [32,33]. Thus, we sought to investigate if there is crosstalk between Panx 1 channels and purinergic receptors during the wound healing process. We confirmed the P2X7 and P2Y2 receptors (P2X7R and P2Y2R) expression in these cells (Figure 4C). Then, we evaluated if these receptors are involved in the wound healing process by performing the wound healing assay in the presence of purinergic antagonists including $100 \mu \mathrm{M}$ suramin (for P2X and P2Y), $200 \mu \mathrm{M}$ brilliant blue G (BBG, for P2X), or $10 \mu \mathrm{M}$ A-740003 (for P2X7R) [34]. All these antagonists were found to accelerate the wound healing process and to reduce the wound area, with A-740003 being the most effective (Figure $4 \mathrm{D}, \mathrm{E}$ ). Indeed, this antagonist reduced the wound area by almost $90 \% 12 \mathrm{~h}$ after the injury (scrape) (Figure $4 \mathrm{D}, \mathrm{E}$ ), similar to the effect obtained using Panx1 blockers (Figure 1). Interestingly, the migration of HDF cells was not affected by treatment with a selective agonist or antagonist of P2Y2R, $10 \mu \mathrm{M}$ MRS-2768, and $10 \mu \mathrm{M}$ AR-C118925 (Supplementary Figure S4). These results support the involvement of P2X7Rs in the healing process.

To determine if there is crosstalk between P2X7R and Panx1 channels during wound healing, we applied the P2X7R antagonists in fibroblasts derived from MDFPanx1-/- mice. In contrast to the effect observed in $\mathrm{HDFs}$, the purinergic blockers did not decrease the wound area in $\mathrm{MDF}^{\mathrm{Panx} 1-/-}$, and suramin and BBG increased it (Supplementary Figure S2E,F), probably unmasking the effects of other purinergic receptors on cell migration and/or proliferation $[9,35,36]$. Taken together, the pharmacological inhibition and genetic knockout data strongly suggest that P2X7R contributes to cell migration through a process that depends on Panx1 channels.

To determine if extracellular ATP is mediating this process, we added $1 \mathrm{mM}$ ATP to the extracellular milieu and measured the wound healing rate (Figure $4 \mathrm{~F}, \mathrm{G}$ ). We found that exogenous ATP slightly accelerated ( 15\%) the wound healing process. Nevertheless, incubation with $1 \mathrm{mM}$ ATP did reduce the healing process acceleration induced by PBN and A-740003, suggesting that extracellular ATP is acting downstream of Panx1 channels. Since it seems contradictory to the observation that $1 \mathrm{mM}$ ATP tends to accelerate the healing process in control HDFs, but the same treatment reduced the closure area induced 
by treatments with PBN or A-740003 (Figure 4F,G), we investigated whether the effect of ATP on the wound healing process is concentration-dependent. Indeed, incubation of HDF cells with different ATP concentrations clearly showed that only higher ATP doses produce significant acceleration of wound healing in HDF cultures (Supplementary Figure S5).

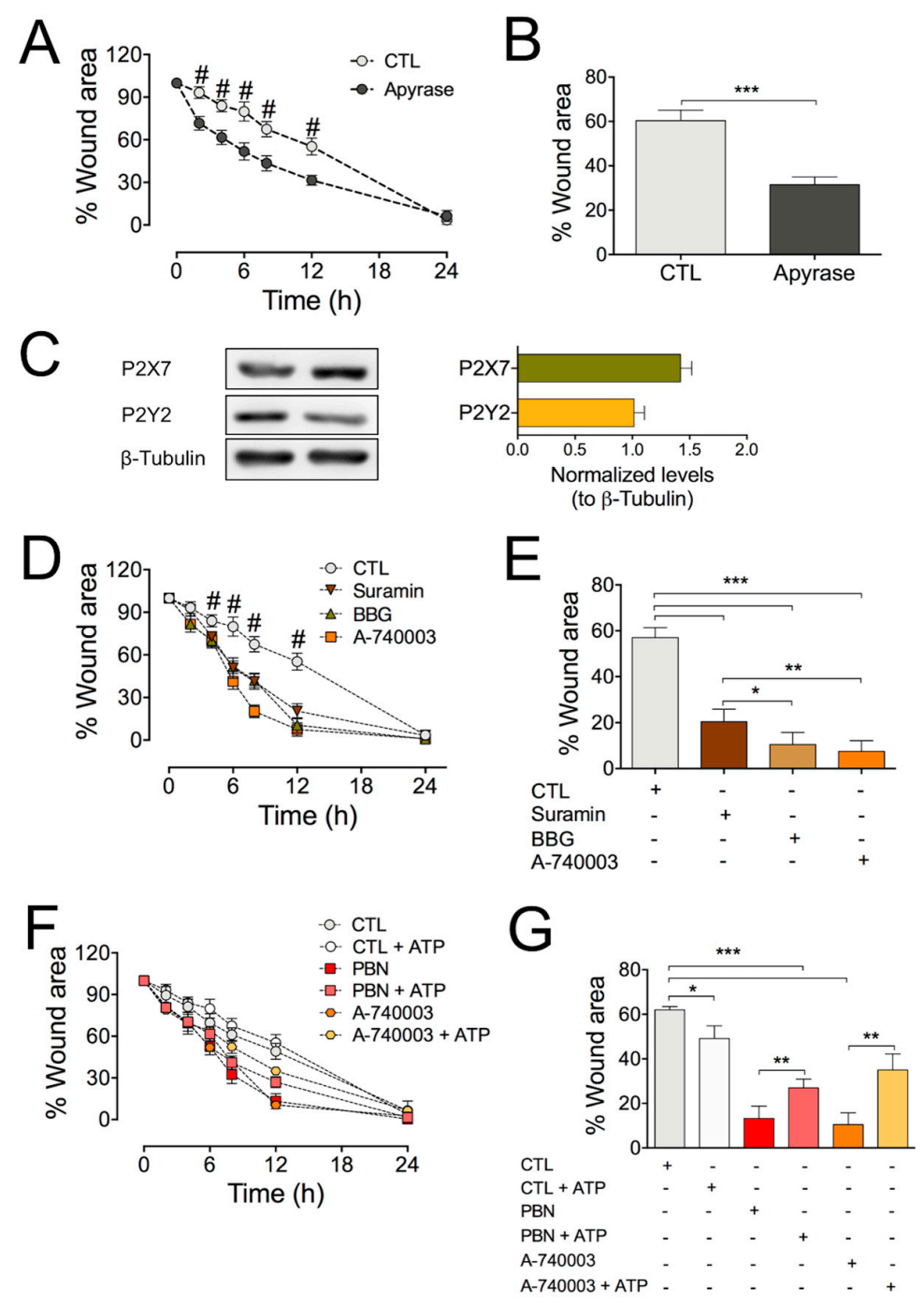

Figure 4. Blockade of the P2X7 receptor accelerates in vitro wound healing in HDF cultures. (A) Determination of the effect of exposure to $10 \mathrm{U} / \mathrm{mL}$ apyrase on the rate of wound healing assay in HDFs. Comparison between Apyrase and control (CTL); \# =*** $p<0.001$ for 2, 4, 6, 8, and $12 \mathrm{~h}$; $n=8$ (one-way ANOVA followed by Bonferroni's post hoc test). (B) Comparison of the reduction in the wound area induced by respective treatments at $12 \mathrm{~h}$ of inducing the wound; *** $p<0.001$; $n=8$ (unpaired two-tailed t-test). (C) Representative Western blot images showing the expression of P2X7R and P2Y2R in two homogenates of HDF cells; $\beta$-tubulin was used as a loading control. Graphs depicting the relative amount of P2X7R and P2Y2R normalized to $\beta$-Tubulin from 8 different cultures. (D) Effects of purinergic receptor antagonists on wound healing assay in HDF cultures. Treatments against control (CTL). \# $=* * * p<0.001$ for 6,8 , and $12 \mathrm{~h} ; n=10$ (one-way ANOVA followed by Bonferroni's post hoc test). (E) Percentage of wound area closure $12 \mathrm{~h}$ after inducing wound in HDF cultures treated with different purinergic receptor antagonists. (F) Determination of the wound healing rate under sustained application of $1 \mathrm{mM}$ ATP in the absence or presence of PBN or A-740003 in HDFs. (G) Effect of exogenous ATP on wound area closure $12 \mathrm{~h}$ after inducing wound in absence or presence of PBN or A-740003. ${ }^{*} p=0.0260 ;{ }^{* *} p=0.087 ;{ }^{* * *} p<0.001 ; n=8$ (one-way ANOVA followed by Bonferroni's post hoc test). All data are shown as mean \pm SEM. 


\subsection{Blocking Panx1 Channels Increases Cell Motility and Triggers Fast Rearrangements of Cell Surface Actin Filaments}

As seen in Figure 1, the rapid wound healing elicited in vitro by Panx1 channel blockers strongly suggests that cell motility is somehow under Panx1 control. To test this hypothesis, we measured rapid cell shape changes over time and determined the motility index (see Section 4). While the motility index did not change under control conditions, we found that the application of $200 \mu \mathrm{M}$ PBN rapidly increased the motility index (Figure 5A,B), which was associated with an increase in the displacement of isolated HDFs (Figure 5C).

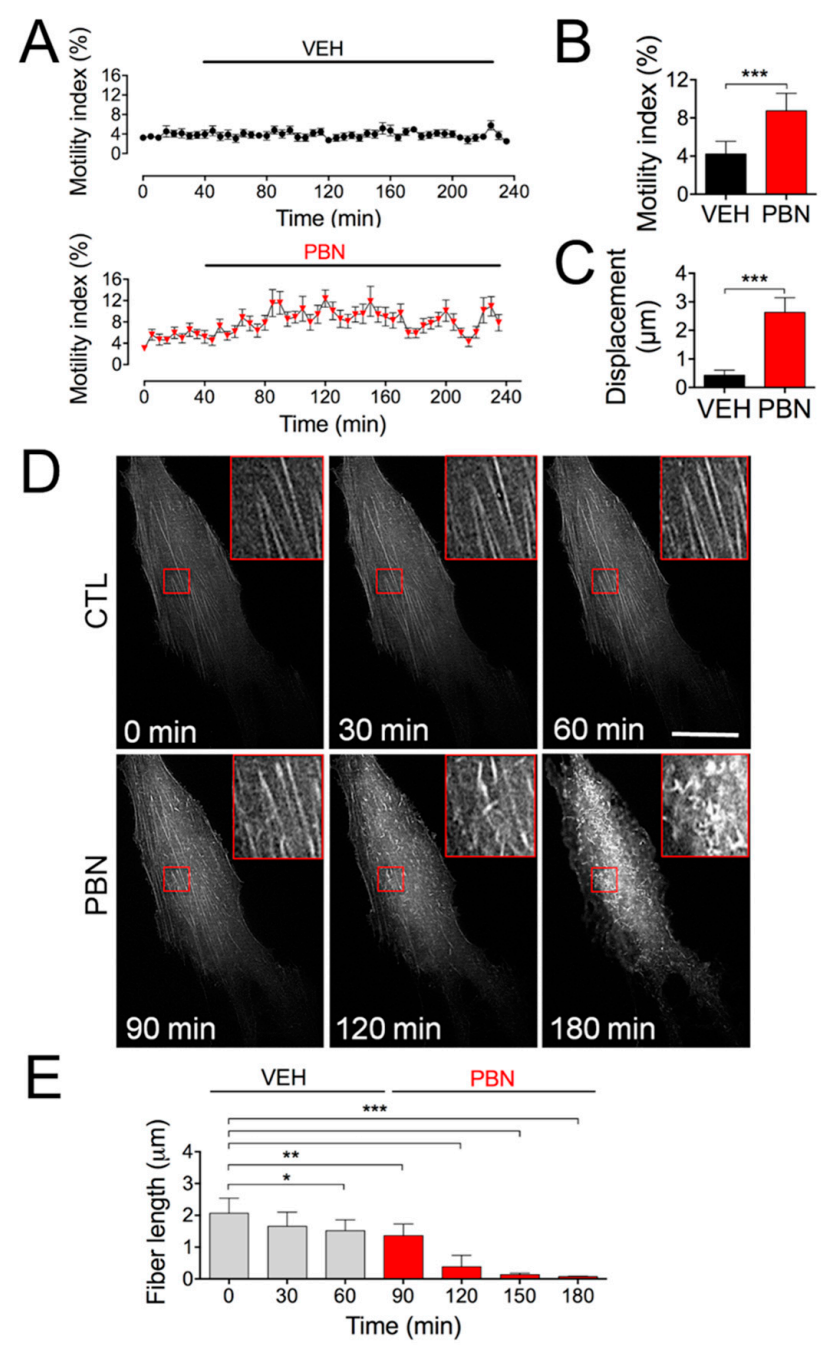

Figure 5. The blockade of Panx1 channels increases single-cell motility and the cell surface actin dynamics. (A) Quantification of motility index during treatment with vehicle (Control, VEH) or probenecid (PBN) in 20 individual HDFs per condition. (B) Quantification of the total average motility index from 20 independent cells analyzed for each condition. ${ }^{* *} p=0.006$; (unpaired twotailed Student's $t$-tests); $n=10$ cells from 4 different cultures. (C) Quantification of total single-cell displacements after $2 \mathrm{~h}$ of treatment with VEH or PBN. ${ }^{* *} p<0.001 ; n=10$ cells from 4 different cultures (unpaired two-tailed Student's $t$-tests). (D) Representative in vivo imaging taken with TIRF microscopy of actin cytoskeleton dynamics in HDFs. The stress fibers were identified as Life-Act-RFPlabeled filaments; $200 \mu \mathrm{M}$ PBN was added to the culture at $70 \mathrm{~min}$; hence, the image taken at $120 \mathrm{~min}$ corresponds to $50 \mathrm{~min}$ treatment with PBN. The images on the right side are magnified images of the lower's magnification, corresponding to red boxed areas. Bar: $25 \mu \mathrm{m}$. (E) Quantitative analysis of stress fibers' length before and after incubation with PBN. ${ }^{*} p=0.02 ;{ }^{* *} p<0.01 ;{ }^{* * *} p<0.001$; $n=10$ experiments (30 cells analyzed for each repeat) (one-way ANOVA followed by Bonferroni's post hoc test). All data are shown as mean \pm SEM. 
To further study how the Panx 1 channel activity impacts the cellular machinery required for cellular motion, we investigated whether the blockade of these channels affects cell surface actin filaments. For this, HDFs were transfected with LifeAct-RFP, a fungus-derived peptide that binds to F-actin, allowing real-time visualization of microfilament dynamics [37]. Performing TIRF microscopy and video imaging, we observed F-actin stress fibers' depolymerization when the cells were treated with PBN for 70 min (Figure 5D,E; 120 min of recording time), and this depolymerization was further increased at $180 \mathrm{~min}$ (Figure 5D,E). Together, these results suggest that signaling through Panx1 channels controls actin microfilament dynamics.

\section{Discussion}

Wound healing is a complex process that is essential for skin homeostasis. Dermal fibroblasts are essential for cutaneous wound repair because they migrate to the side of the damage, repopulate the wound area, and remodel fibrin and collagen deposits. All these processes require several finely orchestrated steps [38].

The present study shows that Panx1 channels in conjunction with P2X7Rs regulate cell migration during the wound healing process. Our findings using HDFs are consistent with those published with mice keratinocytes, in which cells from Panx1 knock-out animals (Panx1 KO) were found to migrate more efficiently than did wild-type (WT) cells [21]. However, the findings that inhibition of Panx1 channels with carbenoxolone or ${ }^{10} \mathrm{Panx}$ prevents the migration of neutrophils induced by chemoattractants [39-41] and that Panx1 knockdown with siRNA or its blockage with PBN reduces the rate of wound closure and enhances neurite outgrowth in N2a cells [28,42] suggest that the role of Panx1 channels and of purinergic signaling in cell migration is cell type-dependent. We cannot discount the possibility that Panx3 is also involved in regulating cell migration since treatment with siRNA against Panx 3 also accelerates the wound healing process of HDF cultures, although it did so to a lesser extent than did inhibition of Panx1. In addition, recent findings point to a role of Panx3 in in vivo wound healing after skin punch lesions, and Panx3-knock-out mice have reduced healing and collagen remodeling compared to wild-type animals [22].

Panx1 channels have been reported to regulate the proliferation of human subcutaneous fibroblasts, glioma cell lines, neural stem cells, and progenitor cells [20,23,28,43,44]. Therefore, we performed the wound healing experiments in HDF cells synchronized by serum starvation before and during the wound healing protocol. Serum deprivation can induce G0 phase cell cycle arrest and reduce the proliferation of most cell types [45]. Accordingly, our PCNA immunoreactivity measurements showed that Panx1 channel blockers do not affect cell proliferation, confirming that the healing process occurred through a process of migration rather than through cell proliferation.

It has previously been shown that scratch wounds cause the release of approximately $\sim 50-100 \mu \mathrm{M}$ ATP from damaged cells to the culture medium [46]. Under basal conditions, ATP is present in concentrations of approximately $1 \mathrm{mM}$ inside the cell and approximately $1 \mathrm{nM}-1 \mu \mathrm{M}$ outside the cell [47,48]. In our experiments, we observed ATP media concentrations in a nanomolar range after inducing the wound. The finding that Etd uptake rate and ATP release were largely reduced by treatment with Panx1 blockers suggests that Panx1 channels are open during the wound healing process and contribute to a signaling mechanism involved in the activation and migration of HDFs.

Since treatment with apyrase also tends to accelerate HDF migration during wound healing, we thought that purinergic signaling is also involved in controlling HDF migration associated with the activation of Panx1 channels. ATP released through Panx1 channels activates purinergic receptors, particularly P2X7Rs [1,7,49]. Consistent with this hypothesis, treatments with A-740003 or BBG, two P2X7Rs antagonists, also accelerate the wound healing process, suggesting that Panx1 channels and P2X7Rs modulate HDF migration during wound healing through an autocrine/paracrine signaling process. In fact, our findings that $\mathrm{MDF}^{\mathrm{pan} \times 1-{ }^{-}-}$migrates faster than wild-type MDFs, and even faster than HDFs, may be related to the reduced ATP concentration found in the MDFpanx1-/- extracellular medium during the process of wound closure. The finding that inhibition of Panx1 chan- 
nels with PBN causes a significant reduction in ATP release from HDFs and MDFs, but not from MDFpanx1-/- (Supplementary Figure S2G), during wound healing strongly suggests that Panx1 channels are the major contributor to ATP release in fibroblasts. Additionally, we demonstrated that the acceleration of the HDF migration rate treated with Panx1 blockers is partially reverted by exogenous ATP, supporting the idea that activation of purinergic receptors is downstream of Panx1 channels. Another possible mechanism may involve forming a functional intermolecular complex between Panx1 channels and P2X7Rs [30]. The latter is consistent with our finding that the P2X7Rs blocker A-740003 is capable of inhibiting ATP release from HDFs and MDFs, but not from MDFpanx1-/- (Supplementary Figure S2G), suggesting that in our model, ATP may also activate Panx1 channels, supporting the idea that the activation of P2X7R could be both upstream and downstream of Panx1 channel activation. The latter agrees with previous findings that P2X7R activation causes ATP release $[50,51]$ and activation of Panx1 channels $[7,8,52]$. However, we cannot discard that the inhibition of P2X7R with A-740003 affects the Panx1-independent mechanism of ATP release. For example, it has been proposed that P2X7R itself can form a non-selective plasma membrane channel (or macropore) that is permeable to large hydrophilic molecules, such as dyes or ATP [53,54].

On the other hand, it has been described that the elevation of extracellular ATP leads to Panx1 internalization, reducing Panx1 surface expression, and these processes require activation of P2X7Rs $[55,56]$. Therefore, we cannot discard a mechanism in which the over-stimulation of P2X7R with a high ATP concentration may accelerate wound healing. Consistent with this hypothesis, we found that incubation with a high ATP concentration accelerated HDF migration during wound healing. Similarly, exogenous ATP accelerates dendritic cell migration during injury by a mechanism that requires Panx1 channels and P2X7Rs [27].

We cannot dismiss the possibility that other purinergic receptors besides P2X7Rs may be involved in HDF migration regulation. It has been shown that ATP released through Panx1 activates P2Y2Rs, which then activate neutrophils' migration [39-41]. In corneal injury, downregulation of P2Y2Rs decreases the rate of migration of epithelial cells [57]. However, although we found that HDFs express P2Y2Rs, treatment with specific P2Y2R antagonists did not change the wound healing rate, indicating that in HDFs, P2YRs were not involved in regulating migration during wound healing. Extracellular ATP can be dephosphorylated to adenosine by the coordinated action of ecto-apyrase and ecto- 5 ' nucleotidase, and adenosine induces loss of actin stress fibers and cell contraction [58,59] processes that are both required for migration. Unfortunately, we could not test adenosine receptor antagonists or other purinergic receptor antagonists in this study; hence, future studies will be necessary to carry out a more complete pharmacologic analysis of the purinergic signaling involved in this process.

The mechanism by which Panx1 channels control cell motility remains unclear. Still, it is logical to look at the cytoskeleton since it is well known that actin-based cell migration is a key process for morphogenesis and wound healing [60]. Myosin-induced contraction and disassembly of the actin networks generate contraction and forward translocation of the cell body, which is the basis for all cell migration processes [61]. In this regard, an interaction between Panx1 and the actin-related protein 3 (Arp3) [28], an actin cytoskeleton-modulating protein [62], has been demonstrated. Accordingly, pretreatment of neutrophils with carbenoxolone and ${ }^{10} \mathrm{Panx}$ prevented actin polymerization and cell polarization [41]. Moreover, we found that inhibition of Panx1 channels accelerates actin dynamics (depolymerization) on the cell surface, increasing the cell motility index. On the other hand, it has been described that extracellular ATP in the micromolar to millimolar range markedly redistributes actin filaments towards the plasma membrane $[63,64]$. The nature of the distribution of actin filaments varies depending on cell types, such as fibroblast, and the exposure to high concentrations of extracellular ATP, above or equal to $1 \mathrm{mM}$, is known to increase contractile stress fibers $[65,66]$ and can generate contractile forces by depolymerization of cytoskeletal filaments [67]. Yet higher concentrations of extracellular 
ATP have an inhibitory effect on actin nucleation/polymerization (e.g., by phosphorylating a capping or actin-binding protein) $[68,69]$.

On the other hand, Bao and co-workers [70] proposed that ATP released through Panx1 channels triggers a signaling cascade that involves increases in intracellular $\mathrm{Ca}^{2+}$ that regulate actomyosin-mediated mechanics during cell migration. However, this hypothesis needs to be tested. Another more speculative hypothesis is that Panx 1 channels, by allowing constitutive leakage of intracellular ATP to the extracellular milieu or increasing influx of extracellular $\mathrm{Ca}^{2}$, control the intracellular $\mathrm{Ca}^{2+}$ and ATP concentrations, both of which are critical for actin polymerization. Clearly, the mechanism that links Panx1 channels activity and cytoskeletal dynamics during migration need to be further explored.

In summary, we found that Panx1 channels and purinergic signaling through P2X7Rs and/or other yet to be identified purinergic receptors modulate HDF migration. Figure 6 shows the simplest model that can explain our results, in which the activity of Panx1 channels favors ATP release after wound induction, and ATP, acting through P2X7Rs, reduces fibroblast migration. Thus, blocking Panx1 channels or P2X7Rs accelerates migrations during in vitro wound healing. However, higher ATP doses, acting through P2X7R or other purinergic receptors, accelerate cell motility and cell migration, as in the find-me signals.

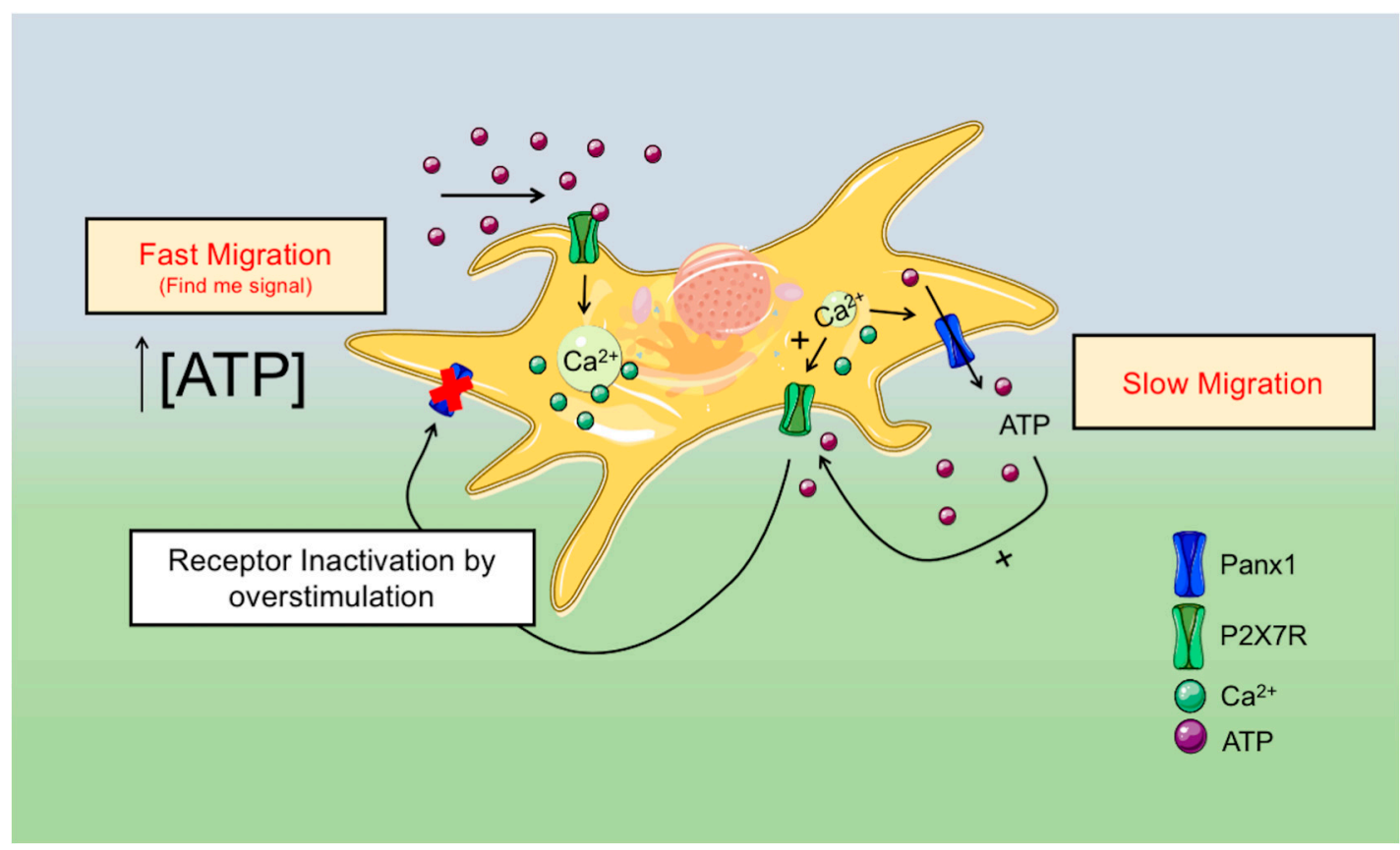

Figure 6. Proposed model for Panx1 channels' role in HDF migration and cell surface actin dynamics.

\section{Materials and Methods}

\subsection{Animals}

Wild-type C57BL/6J or C57BL/6J-Panx1 $1^{-/-}$mice were used. Panx $1^{-/-}-\mathrm{KO}$ mice were generated as described previously [71]. Mice were housed at $22{ }^{\circ} \mathrm{C}$ under constant humidity ( $55 \%$ ), with a $12 / 12 \mathrm{~h}$ dark-light cycle, with free access to food and water. The use and animal care protocols were approved by the Ethics and Animal Care Committee of Universidad de Valparaíso for doctoral project (BEA-139; 10 June 2019) and for FONDECYT grant 1171240 (BEA-102; 22 May 2017).

\subsection{Human and Mice Fibroblast Cell Cultures}

Primary human dermal fibroblasts (HDFs) were provided by Dr. Caroline Weinstein. HDFs were obtained from biopsies of healthy abdominal skin from 4 patients who underwent regenerative autograft surgery. Only remnant, clinically healthy skin, not required for diagnostic or surgery purposes, was used. HDF cultures from biopsies were prepared as 
in [72] with modification. First, the biopsy was extensively washed with sterile phosphate saline buffer ( $\mathrm{pH}$ 7.35). Then, it was mechanically disrupted, using sterile scalpels, and incubated in collagenase $(3 \mathrm{mg} / \mathrm{mL})$ (Nordmark, Uetersen, GE; medical grade) for $1 \mathrm{~h}$ within an incubator $\left(37^{\circ} \mathrm{C}, 5 \% \mathrm{CO}_{2}\right.$, and humidified atmosphere). After this, the mixture was centrifuged at $553 \times \mathrm{g}$, and the pellet was cultured in Dulbecco's modified Eagle's medium: nutrient mixture F-12 (Thermo Fisher Scientific, Cambridge, MA, USA), 10\% inactivated fetal bovine serum (Biological Industries, Cromwell, CT, USA) 10,000 IU/mL penicillin, and $10 \mu \mathrm{g} / \mathrm{mL}$ streptomycin (Thermo Fisher Scientific, Waltham, MA, USA), in a $5 \% \mathrm{CO}_{2}$ atmosphere at $37^{\circ} \mathrm{C}$. HDFs from abdominal skin were characterized mainly by morphological criteria. These cultures present long spindle-shaped cells, stellate-shaped cells with fibroblastic extensions, and small round dividing primary cells.

Primary cell cultures of mice dermal fibroblasts (MDFs) were obtained from isolated neonatal skin cells essentially as described previously [73]. Briefly, the skin of euthanized 0 -4-day-old mice was incubated overnight with a solution containing $3 \mathrm{mg} / \mathrm{mL}$ collagenase II (300 U/mg, Worthington, Lakewood, NJ, USA), $100 \mathrm{IU} / \mathrm{mL}$ penicillin, and $100 \mu \mathrm{g} / \mathrm{mL}$ streptomycin (HyClone, Missouri, TX, USA). The epidermis was separated from the dermis, minced, and centrifuged (at 14,000 rpm for $5 \mathrm{~min}$ at $20^{\circ} \mathrm{C}$ ). Cells were grown until confluence in culture flasks containing Dulbecco's modified Eagle's medium: nutrient mixture F-12 (Thermo Fisher Scientific, Waltham, MA, USA), 10\% heated inactivated fetal bovine serum (Gibco, Waltham, MA, USA), and 10,000 IU/mL penicillin/streptomycin (Thermo Fisher Scientific, Waltham, MA, USA), in a $5 \% \mathrm{CO}_{2}$ atmosphere and maintained at $37^{\circ} \mathrm{C}$. The maximum number of passages for all primary cultures was two. All experiments were performed $24 \mathrm{~h}$ after transfection unless otherwise indicated.

\subsection{Determination of the Amount of Pannexins $m R N A$}

Total RNA from HDFs were isolated using the SV Total RNA Isolation System following the manufacturer's instructions (Promega, Madison, WI, USA), and cDNA synthesis was performed using the SUPERSCRIPT III First-Strand System kit (Thermo Fisher Scientific, Waltham, MA, USA). Hot start PCR was performed using 2 ng cDNA in a total volume of $50 \mu \mathrm{L}$ containing DreamTaq Green PCR Master Mix (Thermo Fisher Scientific, Waltham, MA, USA).

The primer sequences were as follows: human-Panx1, Forward: (5'-GCTATTACTT CAGCCTCTCC-3'), Reverse: (5'-CAGTATCTCCACCAAGAACC-3'); human-Panx3, Forward: (5'-AGGGCTGCTAAGTGATGAGA-3'), Reverse: (5'-GAGGTGTTTGGGTTTTGAGG-3'). PCR reactions were performed using 40 cycles and amplified $P C R$ products were visualized in a $3 \%$ agarose gel.

\subsection{Determination of Relative Amount of Proteins}

The total amount of proteins was determined in cultured dermal fibroblasts and for siRNA-transfected dermal fibroblasts. For this, cells were lysed and homogenized in lysis buffer $(150 \mathrm{mM} \mathrm{NaCl}, 10 \mathrm{mM}$ Tris- $\mathrm{HCl}, \mathrm{pH}$ 7.4, EDTA $2 \mathrm{mM}, 1 \%$ Triton X-100, and $0.1 \%$ SDS), supplemented with a protease and phosphatase inhibitor cocktail (Thermo Scientific, Rockford, IL, USA). Protein concentration was then determined with the Qubit ${ }^{\circledR}$ Protein Assay Kit (Thermo Scientific, Rockford, IL, USA). For Western analyses, $40 \mu \mathrm{g}$ of protein was separated by 10\% SDS-PAGE, followed by immunoblotting on PVDF membranes (BioRad, Hercules, CA, USA) with PBS containing $5 \%$ bovine serum albumin and $1 \%$ Tween-20 for $1 \mathrm{~h}$ at room temperature. Membranes were then incubated with specific antibodies against Panx1 (rabbit anti-Panx1, ABN242 Merck; 1:1000), Panx3 (rabbit antiPanx3, 433,270 ThermoFisher, 1:1000), P2X7R (rabbit anti-P2X7, ab3458 Abcam; 1:1000), P2Y2 (mouse anti-P2Y2, ab168535 Abcam; 1:1000), PCNA (mouse anti-PCNA, P8825 Sigma-Aldrich, 1:1000), $\beta$-Tubulin (mouse anti- $\beta$-tubulin, sc-5274, Santa Cruz; 1:1000), and GAPDH (mouse anti-GAPDH, sc-47724, Santa Cruz; 1:1000). Membranes were then incubated with a horseradish peroxidase-labeled secondary antibody (HRP-linked secondary 
anti-mouse or anti-rabbit antibody (111-005-003, 315-005-003; Jackson Immuno Research; 1:5000) for $1 \mathrm{~h}$ at room temperature.

Finally, protein bands were visualized using an enhanced chemiluminescence kit (ECL, BioRad, Hercules, CA, USA) and detected using the image acquisition system Epichemi3 Darkroom (UVP Bioimaging System, Upland, CA, USA). Densitometric analysis was performed using the Image J software (version $1.49 \mathrm{v}$; NIH, Bethesda, MD, USA).

\subsection{In Vitro Scratch Wound Assay}

Fibroblast migration was analyzed as previously described [74]. A wound was created through the cell monolayer using a $200 \mu \mathrm{L}$ pipette tip. When required, cultured cells were then incubated with Panx1 channel blockers: $200 \mu \mathrm{M}$ probenecid (PBN) (Thermo Fisher Scientific, Waltham, MA, USA), $100 \mu \mathrm{M}{ }^{10}$ Panx mimetic peptide, or scrambled mimetic peptide ${ }^{10} \operatorname{Panx}\left(\mathrm{Sc}{ }^{10} \mathrm{Panx}\right) 100 \mu \mathrm{M}$ (Tocris, St. Louis, MO, USA). The wound areas were measured for $24 \mathrm{~h}$, and standardized digital images were acquired every $2 \mathrm{~h}$ using a phase-contrast Nikon Eclipse TE200-U microscope (Nikon Instruments, Melville, NY, USA). Image analysis was performed using Image (version $1.49 \mathrm{v} ; \mathrm{NIH}, \mathrm{MD}, \mathrm{USA}$ ). Wound area $=100 \%$ - percentage of the initial wound area size.

The purinergic receptor antagonists used here were: $10 \mu \mathrm{M}$ A-740003 (Tocris, MO, USA), $100 \mu \mathrm{M}$ suramin (Sigma-Aldrich, St. Louis, MO, USA), $200 \mu \mathrm{M}$ Brilliant Blue G (BBG, Sigma-Aldrich, Louis, MO, USA), $10 \mu \mathrm{M}$ AR-C118925XX (Tocris, St. Louis, MO, USA), $5 \mu$ M MRS-2768 (Tocris, Louis, MO, USA), and 1 mM ATP (Sigma-Aldrich, Louis, $\mathrm{MO}$, USA). Purinergic receptor antagonists and agonists were incubated for $30 \mathrm{~min}$ before inducing the wound and maintained for the experiment's duration.

\subsection{Knockdown of Panx1 and Panx3 Expression by siRNA}

The knockdown expression of either Panx1 and Panx3 was achieved using the psiRNA ${ }^{\mathrm{TM}_{-}}$ GFP System (InvivoGen, San Diego, CA, USA), with target sequences for Panx1 (GTGGACAAGATGGTCACATGT) and Panx3 (GTGAGCTGGACAAGTCTTACA). Fibroblast cultures growing in $35 \mathrm{~mm}$ plates at $60-70 \%$ confluence were transiently transfected with $2 \mu \mathrm{g}$ siRNA using Lipofectamine 2000 (Thermo Fisher Scientific, Waltham, MA, USA) according to the manufacturer's instructions. The GFP reporter gene was used to identify transfected cells. Digital images were acquired using a phase-contrast Nikon Eclipse T3E200-U microscope (Nikon Instruments, Melville, NY, USA) with a 20X objective. Images acquisition was every $3 \mathrm{~h}$. The migration index used is defined as the proportion of cells expressing siRNA-GFP to non-transfected cells present in the migration front of the wound area (ten to fifteen cell rows from the migration front). Specific silencing was confirmed by Western blot.

\subsection{Measurement of ATP Concentrations}

Extracellular ATP was quantified using the luciferin-luciferase ATP determination assay kit (Thermo Fisher Scientific, Waltham, MA, USA). Fibroblasts were plated at 10,000 cells per well. Twenty-four hours later, $200 \mu \mathrm{M}$ PBN or $10 \mu \mathrm{M}$ A-740003 was added to different plates. After inducing the wound, the cell media were collected every $3 \mathrm{~h}$ and clarified by centrifugation at $1200 \times \mathrm{rpm}$. Five aliquots of $5 \mu \mathrm{L}$ samples were collected after $30 \mathrm{~min}$ of incubation with the blocker and mixed with $45 \mu \mathrm{L}$ ATP-mix solution in a white-bottomed 96-well plate (Corning Inc., Corning, NY, USA). Luminescence was determined using a BioTek Synergy HT plate reader (BioTek, Winooski, VT, USA). ATP levels were calculated from raw luminescence values, using the standard curves made with ATP concentration ranging from $1 \mathrm{nM}$ to $1 \mu \mathrm{M}$ in each inhibitor's presence at the appropriate concentration.

\subsection{Dye Uptake Assays}

HDF cultures were initiated on $12 \mathrm{~mm}$ coverslips at different times in order to start wound healing assays every $3 \mathrm{~h}$. HDFs were bathed in physiological extracellular solu- 
tion containing $5 \mu \mathrm{M}$ of ethidium bromide (Etd) and subjected to dye uptake time-lapse imaging as previously described [30]. Dye uptake was recorded using a Nikon Eclipse microscope (Nikon Instruments, Melville, NY, USA) with a 20X objective for time-lapse imaging. Images were captured using a CMOS digital camera (Hamamatsu, ORCA Flash 2.8, C11440, Hamamatsu, JP) every $30 \mathrm{~s}$ for $20 \mathrm{~min}$ to detect changes in fluorescence intensity. The mean Etd fluorescence intensity was measured in each ROI, after background subtraction. Background was evaluated on at least five regions devoid of cell bodies for each analyzed frame. For some experimental conditions, cultured HDFs were preincubated with $200 \mu \mathrm{M}$ PBN, $100 \mu \mathrm{M}{ }^{10}$ Panx, or $100 \mu \mathrm{M} \mathrm{Sc}{ }^{10}$ Panx for 15 min before and during the Etd uptake.

\subsection{Single-Fibroblasts Motility Assay}

Fibroblasts were plated on 25-mm glass coverslips at low confluence (20-30\%) and maintained in recording solution for $1 \mathrm{~h}$ at room temperature. Single-cell images were acquired every $5 \mathrm{~min}$ as described above. One hour after the start of recording, the bath solution was replaced with vehicle or PBN $200 \mu \mathrm{M}$. The motility index was defined as the change in the fibroblast's area $\left(\mathrm{A}_{\mathrm{F}}\right)$ at a fixed focal point for each recording time $\left(\mathrm{t}_{\mathrm{n}}\right)$ by the formula

$$
\mathrm{A}_{\mathrm{F}}=\frac{\mathrm{A}_{\mathrm{Ft} 1}-\mathrm{A}_{\mathrm{Ft} 2}}{\mathrm{~A}_{\mathrm{Ft} 2}} \times 100
$$

Cell borders were analyzed using ImageJ (NIH, Bethesda, MD, USA). Single-fibroblast motility was recorded for $40 \mathrm{~min}$ in control media (vehicle, VEH) and for another $200 \mathrm{~min}$ in media containing $200 \mu \mathrm{M}$ PBN. Videos were recorded using a Nikon TE-2000U inverted microscope (Nikon ACT-2U, Melville, NY, USA), equipped with a 40X objective and DS$2 \mathrm{WBc}$ fast-cooled monochromatic digital camera.

\subsection{Cell Surface Imaging of Actin Fibers}

Fibroblasts growing at $70 \%$ confluences on 25 -mm glass coverslips were transfected with $1 \mu \mathrm{g}$ LifeAct-RFP using Lipofectamine 2000 (Thermo Fisher Scientific, Waltham, MA, USA). Single fibroblasts were recorded for one hour in control media (vehicle) and for another two hours in media containing $200 \mu \mathrm{M}$ PBN. Images of surface actin were acquired every $3 \mathrm{~min}$ for $3 \mathrm{~h}$ using a Nikon Eclipse Ti-TIRF microscope (Nikon Instruments, Melville, NY, USA), equipped with a 60X oil TIRF objective (NA 1.49), laser line 488 and $532 \mathrm{~nm}$, and CMOS digital camera (Hamamatsu, ORCA Flash 2.8, C11440, Hamamatsu, Japan).

\subsection{Data Analysis and Statistics}

For each data set, results are expressed as mean \pm standard error (SEM); $n$ refers to the number of independent experiments. Each set of experiments was conducted with experimental replicas. In most experiments, we used 6-10 experimental replicas from at least 6 different cell cultures. In the case of HDFs, the cell cultures were derived from 4 different human donors. Statistical analyses were performed using GraphPad Prism (version 6, Graphpad Software, Inc., San Diego, CA, USA). Detailed statistical results are included in the figure legends. Normality and equal variances of raw data were probed by the Shapiro-Wilk normality test. Unless otherwise stated, results were analyzed using unpaired two-tailed Student's $t$-tests to compare two groups and ANOVA followed by Tukey's or Bonferroni's post hoc test in the case of multiple groups. A probability of $p<0.05$ was considered statistically significant.

\section{Conclusions}

Our study suggests that Panx1 channels and P2X7Rs modulate the migration of human dermal fibroblasts. However, further investigation is required to identify the mechanism that modulates actin cytoskeleton dynamics under these conditions. Our findings suggest that Panx1 channels play an important role in controlling cell migration during wound healing and tissue regeneration. 
Supplementary Materials: Supplementary Materials can be found at https:/ / www.mdpi.com/1422 $-0067 / 22 / 3 / 1069 /$ s1.

Author Contributions: Conceptualization, C.F.-M. and A.D.M.; methodology, C.F.-M. and A.D.M.; software, C.F.-M.; formal analysis, C.F.-M.; investigation, C.F.-M., J.M., J.V.-N., J.N.-M., and R.C.; resources, A.M.C., C.W.-O., I.E.G., and A.D.M.; data curation, C.F.-M.; writing-original draft preparation, C.F.-M.; writing-review and editing, C.F.-M., I.E.G., D.I.B., A.M.C., C.W.-O., A.C.A., H.A.S., and A.D.M.; visualization, C.F.-M., I.E.G., and A.D.M.; supervision, A.D.M.; project administration, A.D.M.; funding acquisition, A.D.M. All authors have read and agreed to the published version of the manuscript.

Funding: This research was funded by the Fondo Nacional de Desarrollo Científico y Tecnológico (FONDECYT) grant 1171240 (to A.D.M), grant 1160495 (to A.M.C), and grant 11180531 (to I.E.G), Programa de Atracción e Inserción de Capital Humano (PAI) grant 79170081 (to I.E.G), and the Chilean Millennium Centro Interdisciplinario de Neurociencia de Valparaíso grant P09-022F (to A.D.M., A.M.C., and I.E.G). National PhD fellowship from National Research and Development Agency (ANID) 21190247 (CF-M). The authors declare no conflict of interest. The data that support the findings of this study are available from the corresponding author upon reasonable request.

Institutional Review Board Statement: The use and animal care protocols were approved by the Ethics and Animal Care Commit-tee of Universidad de Valparaíso for doctoral project (BEA-139; 10 June 2019) and for FONDECYT grant 1171240 (BEA-102; 22 May 2017). Human dermal fibroblasts were primary cultures that were kindly donated and came from discarded samples used for clinical purposes. Since there is no identification of the patient or his/her data, according to the Institutional Ethics Committee there is no need of informed consent or approval for the use of samples that would be otherwise discarded.

Informed Consent Statement: Not Applicable.

Data Availability Statement: The data presented in this study are available on request to the corresponding author.

Acknowledgments: We thank John Ewer for substantial comments on the manuscript.

Conflicts of Interest: The authors declare no conflict of interest.

$\begin{array}{ll}\text { Abbreviations } \\ \text { Panx } & \text { Pannexin } \\ \text { Conxs } & \text { Connexins } \\ \text { Panx1 } & \text { Pannexin 1 } \\ \text { Panx3 } & \text { Pannexin 3 } \\ \text { P2X7R } & \text { Purinergic receptor P2X7 } \\ \text { P2Y2R } & \text { P2Y2 receptor (P2Y2R) } \\ \text { MDF } & \text { Mouse dermal fibroblast } \\ \text { HDF } & \text { Human dermal fibroblast } \\ \text { MDFpanx1-/- } & \text { Pannexin1 knock-out mouse dermal fibroblast } \\ \text { siRNA } & \text { Small interfering RNA } \\ \text { PBN } & \text { Probenecid } \\ \text { WT } & \text { Wild type } \\ \text { Panx1KO } & \text { Pannexin 1 knock-out } \\ \text { F-actin } & \text { Filamentous actin } \\ \text { Arp3 } & \text { Actin-related protein 3 }\end{array}$

\section{References}

1. Bao, L.; Locovei, S.; Dahl, G. Pannexin membrane channels are mechanosensitive conduits for ATP. FEBS Lett. 2004, 572, 65-68. [CrossRef]

2. Chekeni, F.B. Pannexin 1 channels mediate 'find-me' signal release and membrane permeability during apoptosis. Nature 2010, 467, 863-867. [CrossRef] [PubMed]

3. Penuela, S.; Gehi, R.; Laird, D.W. The biochemistry and function of pannexin channels. Biochim. Biophys. Acta Biomembr. 2013, 1828, 15-22. [CrossRef] [PubMed] 
4. Boassa, D.; Ambrosi, C.; Qiu, F.; Dahl, G.; Gaietta, G.; Sosinsky, G. Pannexin1 channels contain a glycosylation site that targets the hexamer to the plasma membrane. J. Biol. Chem. 2007, 282, 31733-31743. [CrossRef] [PubMed]

5. Surprenant, A.; Rassendren, F.; Kawashima, E.; North, R.A.; Buell, G. The cytolytic P2Z receptor for extracellular ATP identified as a P2X receptor (P2X7). Science 1996, 272, 735-738. [CrossRef]

6. Locovei, S.; Wang, J.; Dahl, G. Activation of pannexin 1 channels by ATP through P2Y receptors and by cytoplasmic calcium. FEBS Lett. 2006, 580, 239-244. [CrossRef]

7. Locovei, S.; Scemes, E.; Qiu, F.; Spray, D.C.; Dahl, G. Pannexin1 is part of the pore forming unit of the P2X7 receptor death complex. FEBS Lett. 2007, 581, 483-488. [CrossRef]

8. Iglesias, R. P2X7 receptor-Pannexin1 complex: Pharmacology and signaling. Am. J. Physiol.-Cell Physiol. 2008, 295, C752-C760. [CrossRef]

9. Burnstock, G.; Knight, G.E.; Greig, A.V.H. Purinergic Signaling in Healthy and Diseased Skin. J. Investig. Dermatol. 2011, 132, 526-546. [CrossRef]

10. Singer, A.J.; Clark, R.A. Cutaneous Wound Healing. N. Engl. J. Med. 1999, 341, 738-746. [CrossRef]

11. Gurtner, G.C.; Werner, S.; Barrandon, Y.; Longaker, M.T. Wound repair and regeneration. Nature 2008, 453, 314-321. [CrossRef]

12. Nobes, C.D.; Hall, A. Rho GTPases control polarity, protrusion, and adhesion during cell movement. J. Cell Biol. 1999, 144, 1235-1244. [CrossRef] [PubMed]

13. Kretz, M. Altered connexin expression and wound healing in the epidermis of connexin-deficient mice. J. Cell Sci. 2003, 116, 3443-3452. [CrossRef]

14. Brandner, J.M.; Houdek, P.; Hüsing, B.; Kaiser, C.; Moll, I. Connexins 26, 30, and 43: Differences among spontaneous, chronic, and accelerated human wound healing. J. Investig. Dermatol. 2004, 122, 1310-1320. [CrossRef]

15. Wang, C.M.; Lincoln, J.; Cook, J.E.; Becker, D.L. Abnormal connexin expression underlies delayed wound healing in diabetic skin. Diabetes 2007, 56, 2809-2817. [CrossRef]

16. Wright, C.S.; Van Steensel, M.A.; Hodgins, M.B.; Martin, P.E. Connexin mimetic peptides improve cell migration rates of human epidermal keratinocytes and dermal fibroblasts in vitro. Wound Repair Regen. 2009, 17, 240-249. [CrossRef]

17. Churko, J.M. Human dermal fibroblasts derived from oculodentodigital dysplasia patients suggest that patients may have wound-healing defects. Hum. Mutat. 2011, 32, 456-466. [CrossRef]

18. Wright, C.S.; Pollok, S.; Flint, D.J.; Brandner, J.M.; Martin, P.E.M. The connexin mimetic peptide Gap27 increases human dermal fibroblast migration in hyperglycemic and hyperinsulinemic conditions in vitro. J. Cell. Physiol. 2012, 227, 77-87. [CrossRef]

19. Penuela, S. Pannexin 1 and pannexin 3 are glycoproteins that exhibit many distinct characteristics from the connexin family of gap junction proteins. J. Cell Sci. 2007, 120, 3772-3783. [CrossRef]

20. Celetti, S.J.; Cowan, K.N.; Penuela, S.; Shao, Q.; Churko, J.; Laird, D.W. Implications of pannexin 1 and pannexin 3 for keratinocyte differentiation. J. Cell Sci. 2010, 123, 1363-1372. [CrossRef]

21. Penuela, S.; Kelly, J.J.; Churko, J.M.; Barr, K.J.; Berger, A.C.; Laird, D.W. Panx1 regulates cellular properties of keratinocytes and dermal fibroblasts in skin development and wound healing. J. Investig. Dermatol. 2014, 134, 2026-2035. [CrossRef] [PubMed]

22. Zhang, P. Pannexin-3 Deficiency Delays Skin Wound Healing in Mice due to Defects in Channel Functionality. J. Investig. Dermatol. 2019, 139, 909-918. [CrossRef] [PubMed]

23. Pinheiro, A.R. Histamine induces ATP release from human subcutaneous fibroblasts, via pannexin- 1 hemichannels, leading to Ca2+ mobilization and cell proliferation. J. Biol. Chem. 2013, 288, 27571-27583. [CrossRef]

24. Cowan, K.N.; Langlois, S.; Penuela, S.; Cowan, B.J.; Laird, D.W. Pannexin1 and Pannexin3 Exhibit Distinct Localization Patterns in Human Skin Appendages and are Regulated during Keratinocyte Differentiation and Carcinogenesis. Cell Commun. Adhes. 2012, 19, 45-53. [CrossRef]

25. Baranova, A. The mammalian pannexin family is homologous to the invertebrate innexin gap junction proteins. Genomics 2004 83, 706-716. [CrossRef]

26. Bruzzone, R.; Hormuzdi, S.G.; Barbe, M.T.; Herb, A.; Monyer, H. Pannexins, a family of gap junction proteins expressed in brain. Proc. Natl. Acad. Sci. USA 2003, 100, 13644-13649. [CrossRef]

27. Saéz, P.J.; Vargas, P.; Shoji, K.F.; Harcha, P.A.; Lennon-Duméni, A.M.; Saéz, J.C. ATP promotes the fast migration of dendritic cells through the activity of pannexin 1 channels and P2X7 receptors. Sci. Signal. 2017, 10, 7107. [CrossRef]

28. Wicki-Stordeur, L.E.; Swayne, L.A. Panx1 regulates neural stem and progenitor cell behaviours associated with cytoskeletal dynamics and interacts with multiple cytoskeletal elements. Cell Commun. Signal. 2013, 11, 62. [CrossRef]

29. Silverman, W.; Locovei, S.; Dahl, G. Probenecid, a gout remedy, inhibits pannexin 1 channels. AJP Cell Physiol. 2008, 295, C761-C767. [CrossRef]

30. Pelegrin, P.; Surprenant, A. Pannexin-1 mediates large pore formation and interleukin-1beta release by the ATP-gated P2X7 receptor. Eur. Mol. Biol. Organ. J. 2006, 25, 5071-5082. [CrossRef]

31. García, I.E. Keratitis-ichthyosis-deafness syndrome-associated Cx26 mutants produce nonfunctional gap junctions but hyperactive hemichannels when co-expressed with wild type Cx43. J. Investig. Dermatol. 2015, 135, 1338-1347. [CrossRef]

32. Solini, A.; Chiozzi, P.; Morelli, A.; Fellin, R.; Di Virgilio, F. Human primary fibroblasts in vitro express a purinergic P2X7 receptor coupled to ion fluxes, microvesicle formation and IL-6 release. J. Cell Sci. 1999, 112, 297-305.

33. Gentile, D. Searching novel therapeutic targets for scleroderma: P2X7-receptor is UP-regulated and promotes a fibrogenic phenotype in systemic sclerosis fibroblasts. Front. Pharmacol. 2017, 8, 638. [CrossRef] 
34. Jacobson, K.A. Agonists and Antagonists for P2 Receptors. In Foundation Symposium; John Wiley: Chichester, NY, USA, 1999 ; p. 58.

35. Jin, H. P2Y2R activation by nucleotides promotes skin wound-healing process. Exp. Dermatol. 2014, 23, 480-485. [CrossRef]

36. Klepeis, V.E.; Weinger, I.; Kaczmarek, E.; Trinkaus-Randall, V. P2Y receptors play a critical role in epithelial cell communication and migration. J. Cell. Biochem. 2004, 93, 1115-1133. [CrossRef]

37. Riedl, J. Lifeact: A versatile marker to visualize F-actin. Nat. Methods 2008, 5, 605-607. [CrossRef]

38. Hata, S.; Okamura, K.; Hatta, M.; Ishikawa, H.; Yamazaki, J. Proteolytic and non-proteolytic activation of keratinocyte-derived latent TGF- $\beta 1$ induces fibroblast differentiation in a wound-healing model using rat skin. J. Pharmacol. Sci. 2014, 124, 230-243. [CrossRef]

39. Chen, Y. ATP release guides neutrophil chemotaxis via P2Y2 and A3 receptors. Science 2006, 314, 1792-1795. [CrossRef]

40. Chen, Y. Purinergic signaling: A fundamental mechanism in neutrophil activation. Sci. Signal. 2010, 3, ra45. [CrossRef]

41. Bao, Y.; Chen, Y.; Ledderose, C.; Li, L.; Junger, W.G. Pannexin 1 channels link chemoattractant receptor signaling to local excitation and global inhibition responses at the front and back of polarized neutrophils. J. Biol. Chem. 2013, 288, 22650-22657. [CrossRef]

42. $\mathrm{Xu}, \mathrm{X}$. Probenecid disrupts a novel pannexin 1-collapsin response mediator protein 2 interaction and increases microtubule stability. Front. Cell. Neurosci. 2018, 12, 124. [CrossRef]

43. Wei, L.; Yang, X.; Shi, X.; Chen, Y. Pannexin-1 silencing inhibits the proliferation of U87-MG cells. Mol. Med. Rep. 2015, 11, 3487-3492. [CrossRef]

44. Orellana, J.A. ATP and glutamate released via astroglial connexin 43 hemichannels mediate neuronal death through activation of pannexin 1 hemichannels. J. Neurochem. 2011, 118, 826-840. [CrossRef]

45. Khammanit, R.; Chantakru, S.; Kitiyanant, Y.; Saikhun, J. Effect of serum starvation and chemical inhibitors on cell cycle synchronization of canine dermal fibroblasts. Theriogenology 2008, 70, 27-34. [CrossRef]

46. Thoumine, O.; Ott, A. Influence of adhesion and cytoskeletal integrity on fibroblast traction. Cell Motil. Cytoskelet. 1996, 35, 269-280. [CrossRef]

47. Yin, J.; Xu, K.; Zhang, J.; Kumar, A.; Yu, F.S.X. Wound-induced ATP release and EGF receptor activation in epithelial cell. J. Cell Sci. 2007, 120, 5818-5825. [CrossRef]

48. Corriden, R.; Insel, P.A. Basal release of ATP: An autocrine-paracrine mechanism for cell regulation. Sci. Signal. 2010, 3, re1. [CrossRef]

49. Romanov, R.A.; Bystrova, M.F.; Rogachevskaya, O.A.; Sadovnikov, V.B.; Shestopalov, V.I.; Kolesnikov, S.S. The ATP permeability of pannexin 1 channels in a heterologous system and in mammalian taste cells is dispensable. J. Cell Sci. 2012, 125, 5514-5523. [CrossRef]

50. Pellegatti, P.; Falzoni, S.; Pinton, P.; Rizzuto, R.; Di Virgilio, F. A novel recombinant plasma membrane-targeted luciferase reveals a new pathway for ATP secretion. Mol. Biol. Cell 2005, 16, 3659-3665. [CrossRef]

51. Brandao-Burch, A.; Key, M.L.; Patel, J.J.; Arnett, T.R.; Orriss, I.R. The P2X7 receptor is an important regulator of extracellular ATP levels. Front. Endocrinol. 2012, 3, 41. [CrossRef]

52. Qiu, F.; Dahl, G. A permeant regulating its permeation pore: Inhibition of pannexin 1 channels by ATP. Am. J. Physiol. Cell Physiol. 2009, 296, C250-C255. [CrossRef] [PubMed]

53. Di Virgilio, F.; Schmalzing, G.; Markwardt, F. The Elusive P2X7 Macropore. Trends Cell Biol. 2018, 28, 392-404. [CrossRef] [PubMed]

54. Karasawa, A.; Michalski, K.; Mikhelzon, P.; Kawate, T. The P2X7 receptor forms a dye-permeable pore independent of its intracellular domain but dependent on membrane lipid composition. eLife 2017, 6, e31186. [CrossRef] [PubMed]

55. Boyce, A.K.J.; Wicki-Stordeur, L.E.; Swayne, L.A. Powerful partnership: Crosstalk between pannexin 1 and the cytoskeleton. Front. Physiol. 2014, 5, 27. [CrossRef] [PubMed]

56. Boyce, A.K.J.; Swayne, L.A. P2X7 receptor cross-Talk regulates ATP-induced pannexin 1 internalization. Biochem. J. 2017, 474, 2133-2144. [CrossRef]

57. Boucher, I.; Rich, C.; Lee, A.; Marcincin, M.; Trinkaus-Randall, V. The P2Y2 receptor mediates the epithelial injury response and cell migration. Am. J. Physiol. Cell Physiol. 2010, 299, C411-C421. [CrossRef]

58. Hashikawa, T. Regulation of adenosine receptor engagement by ecto-adenosine deaminase. FASEB J. 2004, 18, 131-133. [CrossRef]

59. Sohail, M.A. Adenosine induces loss of actin stress fibers and inhibits contraction in hepatic stellate cells via Rho inhibition. Hepatology 2009, 49, 185-194. [CrossRef]

60. Zhu, J.; Mogilner, A. Comparison of cell migration mechanical strategies in three-dimensional matrices: A computational study. Interface Focus 2016, 6, 20060640. [CrossRef]

61. Svitkina, T. The actin cytoskeleton and actin-based motility. Cold Spring Harb. Perspect. Biol. 2018, 10, a018267. [CrossRef]

62. Bhalla-Gehi, R.; Penuela, S.; Churko, J.M.; Shao, Q.; Laird, D.W. Pannexin1 and pannexin3 delivery, cell surface dynamics, and cytoskeletal interactions. J. Biol. Chem. 2010, 285, 9147-9160. [CrossRef] [PubMed]

63. Meijerman, I.; Blom, W.M.; Nagelkerke, J.F. The effect of extracellular ATP on the actin cytoskeleton of hepatocytes. Biochem. Soc. Trans. 1996, 24, 560S. [CrossRef]

64. Meijerman, I.; Blom, W.M.; De Bont, H.J.G.M.; Mulder, G.J.; Nagelkerke, J.F. Nuclear accumulation of G-actin in isolated rat hepatocytes by adenine nucleotides. Biochem. Biophys. Res. Commun. 1997, 240, 697-700. [CrossRef]

65. Joseph, J.; Grierson, I.; Hitchings, R.A. Exogenous ATP causes the contraction of intact fibroblasts in vitro. Exp. Cell Res. 1988, 176, 1-12. [CrossRef] 
66. Ehrlich, H.P.; Rajaratnam, J.B.; Griswold, T.R. ATP-induced cell contraction in dermal fibroblasts: Effects of cAMP and myosin light-chain kinase. J. Cell. Physiol. 1986, 128, 223-230. [CrossRef]

67. Sun, S.X.; Walcott, S.; Wolgemuth, C.W. Cytoskeletal cross-linking and bundling in motor-independent contraction. Curr. Biol. 2010, 20, R649-R654. [CrossRef]

68. Jahraus, A. ATP-dependent membrane assembly of F-actin facilitates membrane fusion. Mol. Biol. Cell 2001, 12, 155-170. [CrossRef]

69. Kellerman, P.S.; Norenberg, S.; Guse, N. Exogenous adenosine triphosphate (ATP) preserves proximal tubule microfilament structure and function in vivo in a maleic acid model of ATP depletion. J. Clin. Investig. 1993, 92, 1940-1949. [CrossRef]

70. Bao, B.A.; Lais, C.P.; Nauss, C.C.; Morgan, J.R. Pannexin1 drives multicellular aggregate compaction via a signaling cascade that remodels the actin cytoskeleton. J. Biol. Chem. 2012, 287, 8407-8416. [CrossRef]

71. Anselmi, F. ATP release through connexin hemichannels and gap junction transfer of second messengers propagate Ca2+ signals across the inner ear. Proc. Natl. Acad. Sci. USA 2008, 105, 18770-18775. [CrossRef]

72. Weinstein-Oppenheimer, C.R. Design of a hybrid biomaterial for tissue engineering: Biopolymer-scaffold integrated with an autologous hydrogel carrying mesenchymal stem-cells. Mater. Sci. Eng. C 2017, 79, 821-830. [CrossRef]

73. Rittié, L.; Fisher, G.J. Isolation and culture of skin fibroblasts. Methods Mol. Med. 2005, 117, 83-98.

74. Liang, C.C.; Park, A.Y.; Guan, J.L. In vitro scratch assay: A convenient and inexpensive method for analysis of cell migration in vitro. Nat. Protoc. 2007, 2, 329. [CrossRef] 